\section{TRENDS IN STREAMFLOW IN THE IBICUÍ RIVER BASIN, BRAZIL: INFLUENCE OF RICE CROP IRRIGATION}

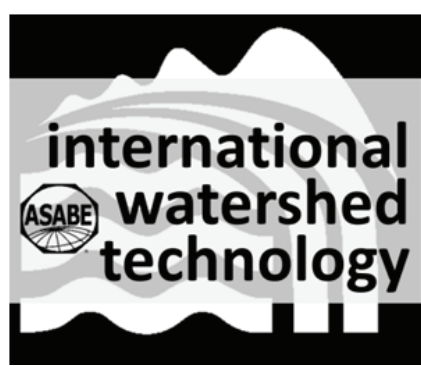

\author{
E. M. C. D. Paiva, C. D. Heatwole, J. B. D. Paiva, \\ R. C. D. Paiva, F. A. Beling
}

\begin{abstract}
The Ibicui River basin in Rio Grande do Sul, Brazil, has recurring problems of water deficits, commonly attributed to the indiscriminate use of water to irrigate rice. The objective of this study was a statistical analysis of water flow data in the Ibicui basin to verify if significant trends in water availability are related to the withdrawal of water for rice crop irrigation. We used data from 11 fluviometric stations for 1970 to 2011, which corresponds to the period of major expansion in rice cultivation in the basin. Daily flows were normalized, and for each month the flow rate was calculated for durations from 50\% to 99\%. Trends in these series were evaluated using the Mann-Kendall test. Results show that over the 40-year period of study there are trends of increasing water flow for eight of the 11 stations, and at six of those eight stations the increasing trend was statistically significant. In a river with sequential stations, differences between the stations indicated a decreasing trend for durations $>80 \%$ as reflected by the Mann-Kendall $Z_{s}$. However, the primary analysis failed to show trends that might reflect increasing irrigation withdrawals. Thus, contrary to expectations, we conclude that, for the Ibicui basin, analysis of trends in the flow data does not clearly implicate water withdrawals for rice irrigation as the reason for water deficits.
\end{abstract}

Keywords. Flow duration, Mann-Kendall test, Rice irrigation, Trend analysis, Water withdrawal.

T he expansion of agricultural land is widely recognized as one of the most significant human alterations to the global environment (Matson et al., 1997). According to Sacks et al. (2008), about $2 \%$ of annual precipitation over land is used for irrigation, and global patterns of irrigation alter the climate significantly in some large regions of the planet.

Brazil has a large agricultural sector. It is the third largest exporter of agricultural products, and it is the ninth largest producer of rice in the world. The state of Rio Grande do Sul accounts for $63 \%$ of the national production of rice. The Ibicuí River basin is among the largest riceproducing areas of the world (RS-DRH, 2010). One of the important environmental problems in the state of Rio Grande do Sul is the significant water withdrawal for rice

Submitted for review in October 2012 as manuscript number SW 9953; approved as a Technical Note for publication by the Soil \& Water Division of ASABE in December 2013.

The authors are Eloiza M. Cauduro Dias de Paiva, Associate Professor, Department of Environmental and Sanitary Engineering, Federal University of Santa Maria, Rio Grande do Sul, Brazil; Conrad D. Heatwole, Associate Professor, Department of Biological Systems Engineering, Virginia Tech, Blacksburg, Va.; João B. Dias de Paiva, Full Professor, Department of Environmental and Sanitary Engineering, Federal University of Santa Maria, Rio Grande do Sul, Brazil; Rodrigo C. Dias de Paiva, Doctoral Student, Institute of Hydraulic Research, Federal University of Rio Grande do Sul, Porto Alegre, Brazil; Fábio A. Beling, Graduate Student, Post-Graduate Program in Civil Engineering, Federal University of Santa Maria, Rio Grande do Sul, Brazil; Corresponding author: Eloiza M. C. D. Paiva, Av. Roraima 1000, Camobi 97105-900, Santa Maria, RS, Brazil; phone: 5555-3220-8483; e-mail: eloiza @ct.ufsm.br. irrigation and the resulting conflicts with other water uses (FEPAM, 2011). Paiva et al. (2000) found that $89 \%$ of the total consumptive use of water in the Ibicuí basin is for rice irrigation, and this is predominantly withdrawals from surface water.

The influence of irrigation withdrawals on water availability for other uses is an obvious concern in a situation of a limited resource. The influence of irrigation on the ecosystem in a more indirect way and on a broader scale has also been shown. Kustu et al. $(2010,2011)$ and DeAngelis et al. (2010) analyzed precipitation, evapotranspiration, streamflow, soil moisture, and water table depth and found evidence that higher rates of evapotranspiration associated with irrigation in the U.S. High Plains have likely caused increased downwind precipitation.

Assessing trends in hydrologic time series data is often of great interest, but it is challenging due to the variability in the data. The Mann-Kendall statistic is frequently used for trend analysis. It is a nonparametric statistic that is widely used for preliminary analyses (Clarke, 2010).

The objective of this study is to determine if there are trends in flow data in the Ibicuí River basin that would reflect a decline in water availability concurrent with the increasing withdrawals for rice irrigation over the past four decades. The approach is to analyze flow data from multiple gauges in the basin that have different fractions of area in rice cultivation in the subbasins. In addition to the flow data, we also analyze rainfall data to identify any trends in this input. 


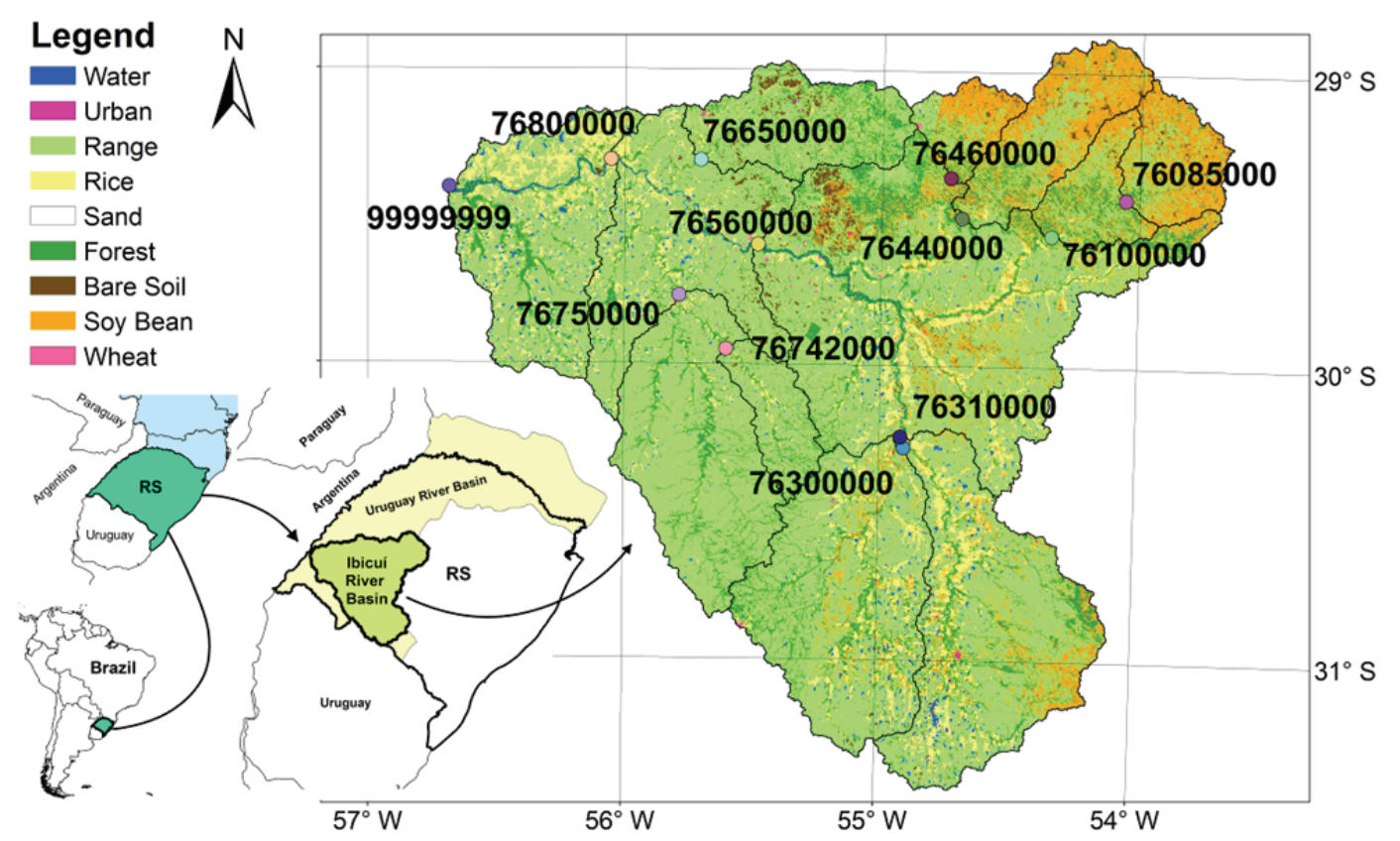

Figure 1. Location, land use, subbasins, and stage stations of the Ibicuí basin.

Table 1. Land use in the Ibicuí basin (classification of 1999 Landsat image).

\begin{tabular}{|c|c|c|c|c|c|c|c|c|c|}
\hline & \multicolumn{9}{|c|}{ Land Cover } \\
\hline & Water & Urban & Range & Sand & Forest & Rice & Bare Soil & Soybean & Wheat \\
\hline Area $\left(\mathrm{km}^{2}\right)$ & 802.0 & 52.5 & $29,727.7$ & 19.1 & $5,456.7$ & $5,136.8$ & $1,040.7$ & $5,413.7$ & 95.5 \\
\hline Percentage & $1.68 \%$ & $0.11 \%$ & $62.27 \%$ & $0.04 \%$ & $11.43 \%$ & $10.76 \%$ & $2.18 \%$ & $11.34 \%$ & $0.20 \%$ \\
\hline
\end{tabular}

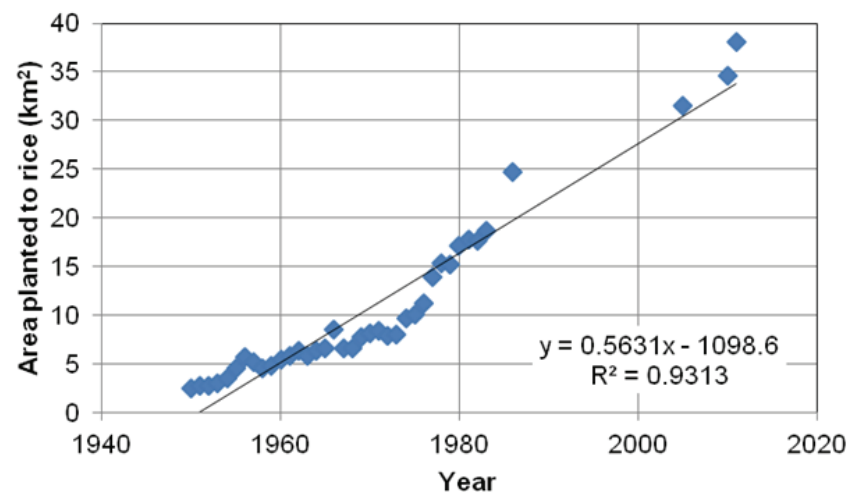

Figure 2. Expansion of rice culture in municipalities encompassing the Ibicuí basin.

\section{THE IBICUÍ BASIN}

The Ibicuí basin is located in the southwest of the state of Rio Grande do Sul and has a drainage area of around $47,740 \mathrm{~km}^{2}$ (fig. 1). It is part of the Uruguay basin and is characteristic of the Pampa biome. The Brazilian Pampa lies within the South Temperate Zone, where grasslands scattered with shrubs and trees are the dominant vegetation. The soil, originating from sedimentary rocks, often has an extremely sandy texture that makes it highly prone to water and wind erosion (Roesch et al., 2009).

The land use in the basin shown in figure 1 was derived from 1999 Landsat imagery, and the percentage of area in different land use classes is given in table 1. In this region, since 1950 , there has been increasing area devoted to rice cultivation. Data from 1950 to 2010 (IRGA, 1988, 2012) show the expansion of the area planted with rice crop in the municipalities that make up the basin (fig. 2).

Eleven stream gauging stations in the basin with daily flow data from 1970 to the present are shown in figure 1 along with the subbasin boundaries. Table 2 presents the percentage of rice-growing area in 1999 for each subbasin.

\section{MeTHODS}

Eleven fluviometric stations that have data covering the period of increasing rice cultivation from 1970 to 2011 were identified in the basin (fig. 1 and table 2). Daily water flow data for the observed period were retrieved from the Brazilian National Water Agency (ANA) website (ANA, 2011). The daily flow values were normalized by reducing each daily flow by the average daily flow of the month and dividing by the standard deviation. Two different data series were analyzed: one with all months of the year, and the other having only the four months corresponding to the rice irrigation season (November to February). The flow at durations from $50 \%$ to $99 \%$ of the time were calculated for each month. The assumption of independence was tested according to Wilks (2006). From the series, we analyzed for trends using the Mann-Kendall test and linear regression. The linear regression results are not presented because they are very similar to the Mann-Kendall test results, which are presented here.

We identified 27 rain gauges in the basin with records covering the period of the flow data, and we analyzed the data to determine if there were trends in rainfall over this 
Table 2. Fluviometric stations and percentage of subbasin area in rice cultivation.

\begin{tabular}{|c|c|c|c|c|c|c|c|}
\hline \multirow[b]{2}{*}{ Station } & \multirow[b]{2}{*}{ Name } & \multirow[b]{2}{*}{ Latitude } & \multirow[b]{2}{*}{ Longitude } & \multicolumn{2}{|c|}{ Data Used } & \multirow{2}{*}{$\begin{array}{c}\text { Area of } \\
\text { Subbasin } \\
\left(\mathrm{km}^{2}\right)\end{array}$} & \multirow{2}{*}{$\begin{array}{l}\text { Area in Rice } \\
\text { Cultivation } \\
\text { in } 1999(\%)\end{array}$} \\
\hline & & & & $\begin{array}{l}\text { Start } \\
\text { Year }\end{array}$ & $\begin{array}{l}\text { End } \\
\text { Year }\end{array}$ & & \\
\hline \multicolumn{8}{|l|}{ Toropi River } \\
\hline 76085000 & Cachoeira 5 Veados & $-29^{\circ} 25^{\prime} 44^{\prime \prime}$ & $-54^{\circ} 03^{\prime} 15^{\prime \prime}$ & 1976 & 2011 & 1541 & 0.04 \\
\hline 76100000 & Vila Clara & $-29^{\circ} 33^{\prime} 21^{\prime \prime}$ & $-54^{\circ} 20^{\prime} 31^{\prime \prime}$ & 1941 & 2011 & 2798 & 0.42 \\
\hline \multicolumn{8}{|l|}{ Santa Maria River } \\
\hline 76300000 & Ponte Ibicuí da Armada & $-30^{\circ} 16^{\prime} 50^{\prime \prime}$ & $-54^{\circ} 54^{\prime} 11^{\prime \prime}$ & 1967 & 2011 & 6007 & 11.74 \\
\hline 76310000 & Rosário do Sul & $-30^{\circ} 14^{\prime} 34^{\prime \prime}$ & $-54^{\circ} 55^{\prime} 00^{\prime \prime}$ & 1967 & 2011 & 12014 & 11.74 \\
\hline \multicolumn{8}{|l|}{ Jaguari River } \\
\hline 76440000 & Jaguari & $-29^{\circ} 29^{\prime} 56^{\prime \prime}$ & $-54^{\circ} 41^{\prime} 21^{\prime \prime}$ & 1941 & 2011 & 2330 & 0.78 \\
\hline 76460000 & Ernesto Alves & $-29^{\circ} 21^{\prime} 45^{\prime \prime}$ & $-54^{\circ} 44^{\prime} 07^{\prime \prime}$ & 1958 & 2011 & 930 & 1.86 \\
\hline \multicolumn{8}{|l|}{ Ibirapuitã River } \\
\hline 76742000 & Passo do Osório & $-29^{\circ} 57^{\prime} 01^{\prime \prime}$ & $-55^{\circ} 36^{\prime} 09^{\prime \prime}$ & 1977 & 2011 & 1163 & 5.93 \\
\hline 76750000 & Alegrete & $-29^{\circ} 46^{\prime} 06^{\prime \prime}$ & $-55^{\circ} 47^{\prime} 13^{\prime \prime}$ & 1940 & 2011 & 5940 & 3.84 \\
\hline \multicolumn{8}{|l|}{ Itú River } \\
\hline 76650000 & Passo da Cachoeira & $-29^{\circ} 18^{\prime} 33^{\prime \prime}$ & $-55^{\circ} 42^{\prime} 20^{\prime \prime}$ & 1962 & 2011 & 2561 & 7.86 \\
\hline \multicolumn{8}{|l|}{ Ibicuí River } \\
\hline 76560000 & Manoel Viana & $-29^{\circ} 35^{\prime} 39^{\prime \prime}$ & $-55^{\circ} 28^{\prime} 53^{\prime \prime}$ & 1967 & 2011 & 29393 & 9.83 \\
\hline 76800000 & Passo Mariano Pinto & $-29^{\circ} 18^{\prime} 33^{\prime \prime}$ & $-56^{\circ} 03^{\prime} 16^{\prime \prime}$ & 1955 & 2011 & 42574 & 9.32 \\
\hline Ibicuí River outlet & & & & & & 47119 & 10.76 \\
\hline
\end{tabular}

same period. Monthly rainfall was normalized similar to the flow data, and the presence of trends was evaluated using the Mann-Kendall test for the four months corresponding to the rice irrigation season (November to February).

The Mann-Kendall test can be applied to a sample of data $\left(x_{1}, x_{2}, \ldots, x_{n}\right)$ of $n$ independent and identically distributed random variables (Douglas et al., 2000; Kustu et al., 2010). The test first ranks the entire set of observations according to time and then successively compares each data value to all data values following in time by evaluating the MannKendall test statistic $\left(Z_{s}\right)$ as:

$$
S=\sum_{i=1}^{n-1} \sum_{j=i+1}^{n} \operatorname{sgn}\left(x_{j}-x_{i}\right)
$$

where $x_{i}$ and $x_{j}$ are the sequential data values, $n$ is the number of observations, and $\operatorname{sgn}()=1$ if $\left(x_{j}-x_{i}\right)>0, \operatorname{sgn}()=0$ if $\left(x_{j}-x_{i}=0\right.$, and $\operatorname{sgn}()=-1$ if $\left(x_{j}-x_{i}\right)<0$.

$$
\begin{gathered}
E(S)=0 \\
\operatorname{var}(S)=\frac{n(n-1)(2 n+5)}{18}=\sigma^{2}
\end{gathered}
$$

For $n$ larger than 10 , the test statistic $Z_{s}$ is determined as:

$$
\begin{array}{ll}
Z_{S}=(s-1) / \sigma & \text { for } S>0 \\
Z_{s}=(s+1) / \sigma & \text { for } S<0 \\
Z_{s}=0 & \text { for } S=0
\end{array}
$$

Hence, $H_{0}$ should not be rejected in a two-sided trend test if $|Z| \leq z_{\alpha / 2}$, where $\alpha$ is the significance level. A positive value of $Z_{s}$ indicates an upward trend, whereas a negative value indicates a decreasing trend.

\section{RESULTS}

Table 3 presents the results of the Mann-Kendall trend analysis for the 11 gauging stations. At the $90 \%$ flow duration for the four-month data series corresponding to the rice irrigation season, the results show that only three stations had negative trends (i.e., decreasing flow), and these trends were not statistical significant $(\alpha=5 \%)$. The other eight stations had trends of increasing water flow, with statistically significant results $(\alpha=5 \%)$ for six of these eight stations. This conclusion is surprising because there are often deficits of water attributed to withdrawals for rice irrigation

\begin{tabular}{|c|c|c|c|c|c|c|c|c|c|c|}
\hline \multirow[b]{2}{*}{ Station } & \multicolumn{7}{|c|}{ All Months } & \multicolumn{3}{|c|}{ November to February } \\
\hline & $50 \%$ & $60 \%$ & $70 \%$ & $80 \%$ & $90 \%$ & $95 \%$ & $99 \%$ & $90 \%$ & $95 \%$ & $99 \%$ \\
\hline 76085000 & $4.48^{*}$ & $4.85^{*}$ & $4.73^{*}$ & $4.98^{*}$ & $5.09 *$ & $4.34 *$ & $4.35^{*}$ & $2.34 *$ & $2.29 *$ & $2.30^{*}$ \\
\hline 76100000 & $7.02 *$ & $7.30 *$ & 7.54 & $7.75^{*}$ & $7.82 *$ & $7.76^{*}$ & $7.51 *$ & $5.88 *$ & $5.85^{*}$ & $5.87^{*}$ \\
\hline 76300000 & -0.48 & -0.48 & -0.65 & -0.92 & -1.20 & -1.37 & -1.58 & -1.13 & -1.32 & -1.42 \\
\hline 76310000 & -1.02 & -0.90 & -0.75 & -0.71 & -0.95 & -1.10 & -1.19 & -0.64 & -0.69 & -0.58 \\
\hline 76440000 & $7.47 *$ & $7.36^{*}$ & $7.08 *$ & $6.75^{*}$ & $6.37 *$ & $5.89 *$ & $5.19 *$ & $5.18^{*}$ & $4.96 *$ & $4.40^{*}$ \\
\hline 76460000 & $3.82 *$ & $4.21 *$ & $4.40^{*}$ & $4.50 *$ & $4.19^{*}$ & $3.88^{*}$ & $3.62 *$ & $4.49 *$ & $4.13 *$ & $3.81^{*}$ \\
\hline 76742000 & -1.59 & -1.53 & -1.36 & -1.10 & -1.01 & -1.07 & -1.08 & -1.65 & -1.77 & -1.72 \\
\hline 76750000 & $2.58 *$ & $2.45^{*}$ & $1.96^{*}$ & 1.66 & 1.39 & 1.08 & 0.85 & 0.85 & 0.55 & 0.34 \\
\hline 76650000 & $5.60 *$ & $6.48 *$ & $7.04 *$ & $7.78 *$ & $8.39 *$ & $8.40 *$ & $8.33 *$ & $6.53 *$ & $6.61 *$ & $6.64 *$ \\
\hline 76560000 & 1.38 & 1.38 & 1.30 & 1.37 & 1.22 & 1.02 & 0.95 & 0.59 & 0.57 & 0.68 \\
\hline 76800000 & $2.66^{*}$ & $2.67 *$ & $2.77^{*}$ & $2.82 *$ & $2.31 *$ & $2.25 *$ & $2.12 *$ & $2.45^{*}$ & $2.67 *$ & $2.68 *$ \\
\hline
\end{tabular}
during the developing period of the crop. River discharge in the period of irrigation (November to February) is typically low, and modeling studies have verified the problem (Collischonn et al., 2011). Although a distinct trend in flow

Table 3. Mann-Kendall $Z_{s}$ values by station at different flow durations for full and partial data series. ${ }^{[a]}$

[a] Asterisks $(*)$ indicate statistical significance at $\alpha=5 \%$. 


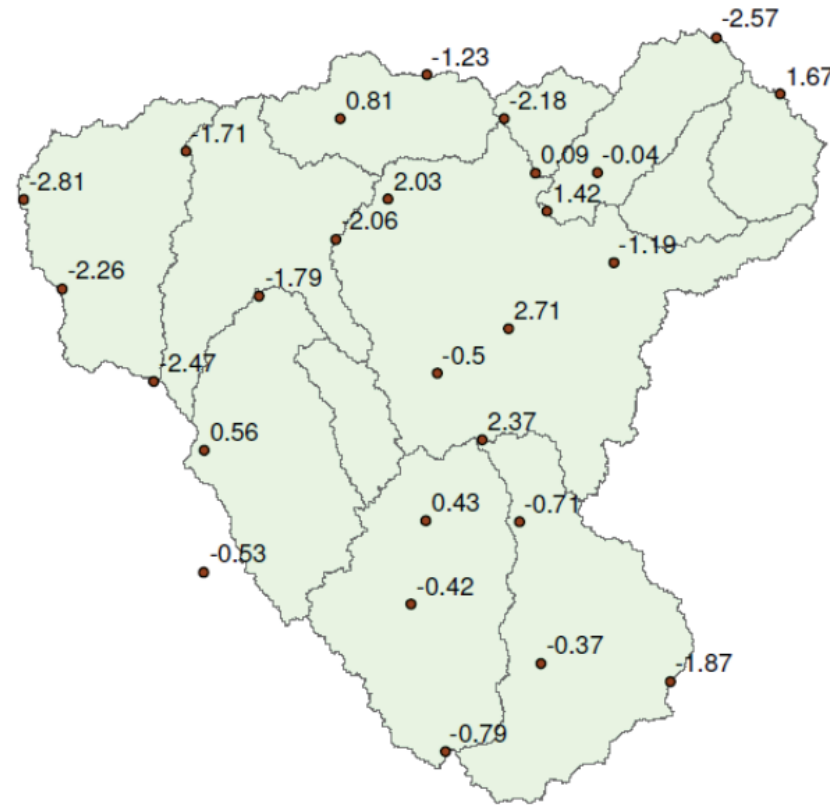

Figure 3. Location of rain gauge stations with Mann-Kendall $Z_{s}$ for annual data.

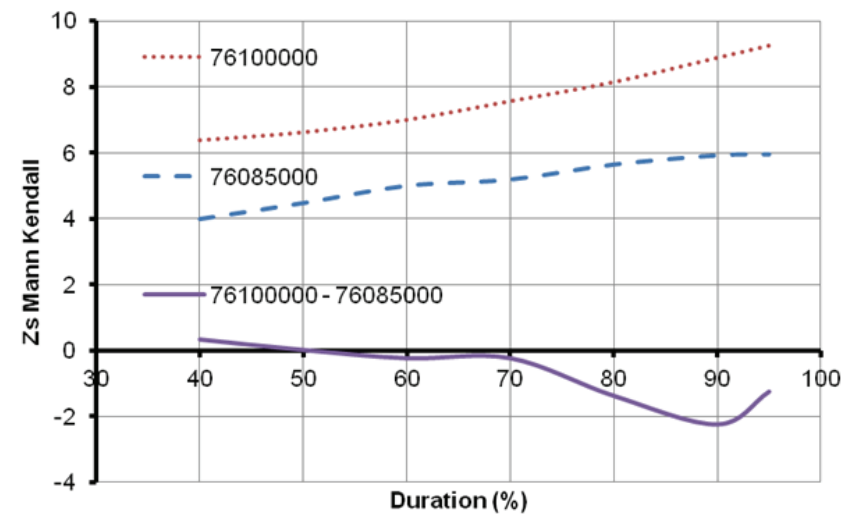

Figure 4. Mann-Kendall Zs for Toropi subbasin stations and the difference between them.

reduction has not been confirmed in this analysis, it can be seen that the subbasins with negative trends were those that have a higher percentage area in rice, specifically the Santa Maria (stations 76300000 and 76310000) and Ibirapuitã (stations 76742000 and 76750000) subbasins.

Results from the analysis of the rainfall data are shown in figure 3 as a map of the basin with Mann-Kendall $Z_{s}$ values at the locations of the 27 rain gauges. Eighteen of the gauges had negative trends (six were statistically significant), and nine had positive trends (three were statistically significant). For the period of rice irrigation (November to February), these trends were close to zero, with only one negative statistically significant trend and two positive statistically significant trends. Thus, analysis of these data does not indicate any distinct trend in rainfall patterns, particularly in the rice irrigation season, that would bias or confound the analysis of the flow data.

Water withdrawals for irrigation of rice in the region are commonly considered to be a source of low flows and water conflicts, yet the results of this trend analysis of flows at
11 individual stations over the four decades of increasing rice cultivation did not reflect the negative impact of irrigation that is commonly assumed. As a further analysis to explore the data, we examined relative changes in flow for the Toropi subbasin, where there are two stations and the majority of rice cultivation occurs below the upstream station. While less than $1 \%$ of the basin area is in rice cultivation, the downstream flow is sometimes less than the upstream flow. The data series of the difference between the downstream (76100000) and upstream (76085000) stations was analyzed for trends, and results are shown in figure 4 . While the trend in flow is increasing at both stations, the difference in flows shows a decreasing trend at greater durations. While we only have one set of stations suitable for this analysis, this is an interesting result that could indicate the influence of rice irrigation, and additional analysis with paired stations should be explored as a way to increase discrimination in analysis of flow trends.

\section{CONCLUSION}

For the Ibicuí River basin, trend analysis did not clearly show an influence of water withdrawals for rice irrigation on decreasing river flows. This result was surprising and contrary to common belief. It is possible that the fluviometric stations were not at locations that could adequately characterize effects of irrigation withdrawals. However, given the number of stations and the length of record used in this analysis, we believe that the results show the common perceptions to be in error. River flows are seasonally low in the November to February period, yet in light of the variability in flow, this analysis finds that withdrawals due to expanding rice cultivation over the past 40 years are not statistically observable as a trend in the data. Analysis of differences for the one available pair of upstreamdownstream station pair showed some evidence of irrigation withdrawals. Further analysis with additional paired stations is recommended.

\section{ACKNOWLEDGEMENTS}

This research was supported by CAPES (Coordenação de Aperfeiçoamento de Pessoal de Nível Superior), UFSM (Universidade Federal de Santa Maria), and the Virginia Agricultural Experiment Station (Hatch Project S1042).

\section{REFERENCES}

ANA. 2011. Dados hidrológico: Séries históricas. In HidroWeb: Sistema de Informaçoes Hidrologicas. Brasilia, Brazil: Agência Nacional de Águas. Available at: http://hidroweb.ana.gov.br. Accessed 15 October 2011.

Clarke, R. T. 2010. On the (mis)use of statistical methods in hydroclimatological research. Hydrol. Sci. J. 55(2): 139-144.

Collischonn, B., R. C. D. Paiva, W. Collischonn, F. S. C. Meirelles, E. B. C. Schettini, and F. M. Fan. 2011. Modelagem hidrológica de uma bacia com uso intensivo de água: Caso do Rio Quaraí, RS. Revista Brasileira de Recursos Hídricos 16(4): 119-134.

DeAngelis, A., F. Dominguez, Y. Fan, A. Robock, M. D. Kustu, and D. Robinson. 2010. Evidence of enhanced precipitation due to irrigation over the Great Plains of the United States. J. Geophys. 
Res. 115: D15115, doi: 10.1029/2010JD013892.

Douglas, E. M., R. M. Vogel, and C. N. Kroll. 2000. Trends in floods and low flows in the United States: Impact of spatial correlation. J. Hydrol. 240(1-2): 90-105.

FEPAM. 2011. Região hidrográfica do Uruguai. Port Alegre, Brazil: Fundação Estadual de Proteção Ambiental Henrique Luiz Roessler, RS. Available at: www.fepam.rs.gov.br/qualidade/ regiao_uruguai.asp. Accessed 2 March 2011.

IRGA. 1988. Anuário estatístico do arroz (19 bi-annual reports from 1952 to 1988). Porto Alegre, Brazil: Instituto Rio Grandense do Arroz.

IRGA. 2012. Área, produção e produtividade: Relatório final municipal da colheita do arroz, 2009/10 e 2010/11. Porto Alegre, Brazil: Instituto Rio Grandense do Arroz. Available at: http://www3.irga.rs.gov.br/uploads/anexos/1329418135Area Producao_e_Produtividade.pdf. Accessed December 2013.

Kustu, M. D., Y. Fan, and A. Robock. 2010. Large-scale water cycle perturbation due to irrigation pumping in the High Plains: A synthesis of observed streamflow changes. J. Hydrol. 390(3-4): 222-244.

Kustu, M. D., Y. Fan, and M. Rodell. 2011. Possible link between irrigation in the U.S. High Plains and increased summer streamflow in the Midwest. Water Resources Res. 47(3):
W03522, doi: 10.1029/2010WR010046.

Matson, P. A., W. J. Parton, A. G. Power, and M. J. Swift. 1997. Agricultural intensification and ecosystem properties. Science 277(5325): 504-509.

Paiva, J. B. D., E. M. C. D. Paiva, M. C. C. Gastaldini, C. A. O. Irion, J. R. Dias, L. C. M. Costa, and L. A. Richter. 2000. Quantificação da demanda de água na bacia do Rio Ibicuí, RS. Revista Brasileira de Recursos Hídricos 5(3): 93-111.

Roesch, L. F. W., F. C. B. Vieira, V. A. Pereira, A. L. Schünemann, I. F. Teixeira, A. J. T. Senna, and V. M. Stefenon. 2009. The Brazilian pampa: A fragile biome. Diversity 1(2): 182-198.

RS-DRH. 2010. Processo de planejamento da bacia hidrográfica do Rio Ibicuí fases A e B. Relatório Técnico 01-RT01. Porto Alegre, Brazil: Estado do Rio Grande do Sul, Departamento DRH/SEMA. Available at: www.comiteibicui.com.br/ planodabacia. Accessed 20 February 2012.

Sacks, W. J., B. I. Cook, N. Buenning, S. Levis, and J. Helkowski. 2008. Effects of global irrigation on the near-surface climate. NASA Publications, Paper 5. Available at: http://igital commons.unl.edu/nasapub/5. Accessed 20 February 2012.

Wilks, D. S. 2006. Statistical Methods in the Atmospheric Sciences. 2nd ed. New York, N.Y.: Elsevier. 